\title{
ROUTE PLAN EVALUATION METHOD FOR PERSONALISED PASSENGER INFORMATION SERVICE
}

\author{
Dávid Földes, Csaba Csiszár \\ Dept of Transport Technology and Economics, Faculty of Transportation Engineering \\ and Vehicle Engineering, Budapest University of Technology and Economics, Hungary
}

Submitted 30 August 2014; resubmitted 19 December 2014, 16 March 2015; accepted 9 April 2015

\begin{abstract}
Due to changing expectations of characteristics of mobility demands, public transportation users increasingly require a reduction of both the preparation and travel time, an easier and more pleasant travelling experience as well as route plans based on reliable data. Both international and domestic research is widely concerned with route planning optimization. Exemplary assistance applications are already in operation, but they are only semi-occasionally and slightly personalized. Consequently, there is potential for significant research and development in this area. Our developed method and algorithm evaluates the routes based on the personalised user settings and in this way, the ideal routes can be determined. User preferences are represented in evaluation criteria. The algorithm also manages network modifications and often-changing user preferences. The novelty of our algorithm lies in the more realistic evaluation of the routes appreciably considering both the exact physical properties of the infrastructure and the users' detailed personal preferences.
\end{abstract}

Keywords: personalized information; route plan; evaluation method; algorithm; public transportation.

\section{Introduction}

Nowadays online route planner applications play an increasingly important role. The individual transportation meets the personal expectations in all regards. The public transportation is unable to satisfy entirely each personal need and expectation. This shortcoming can be moderated in two ways:

- personalization of the basic (transportation) process by demand responsive (flexible) transportation systems;

- advanced information management, as the personalization of the routes.

In these ways customer satisfaction, and therefore their perception of quality of the transportation system can be increased.

We have focused in our research on the information management issues. Meaningful results can be achieved regarding influence of the transportation mode choice by:

- provision of dynamic and real-time information;

- providing information about and consideration of the actual location and circumstances;

- improved personalization.

Applications with dynamic and/or personalised multimodal information can be called Personal Intel- ligent Travel Assistants (PITA) (Chorus, Timmermans 2011), but a significant proportion of the existing route planner applications still use only static data ( $\mathrm{Li}$ et al. 2012). Quality of transportation supply is determined by the quality of:

- service (approachability, directness, time availability, speed, reliability);

- travel (physical and mental comfort, safety and security);

- tractability (perspicuity, information before and during travel) (Duleba et al. 2012).

Accordingly, the real challenge of public transportation is to personalize basic services and information services (Van Oort, Van Nes 2006). Information represents value because on one hand, information management processes are expensive and on the other hand, efficiency of the decisions can be significantly improved by using information. Quality and value of information are closely interrelated. Aspects for description and evaluation of information have been determined in the literature (Leviäkangas 2011).

Multimodal travel is realized by several vehicles and transportation modes. The quality and its assessment depend on attributes of both the travel phases and the travellers. Connection and proportion of infrastruc- 
ture elements in the passenger transportation network are illustrated in Fig. 1. The size of ovals is more or less proportionate to the spatial extension of elements, whereas the segment size is proportionate to the size of shared areas. The figure demonstrates connection of infrastructure elements and the importance of their integrated management, which is especially important in route planner applications.

Transportation mode choice is strongly influenced by the travellers' personal preferences (Csiszár 2013). One of the key issues during the analysis of travel habits is the passengers' reaction to the information; especially the time elements of the certain phases and their uncertainty affect the time of travel (Ettema, Timmermans 2006) and the choice of a transportation mode. Chorus et al. (2013) have studied changes in passengers' decisions as a consequence of the provision of partial information and incrementally more complete information. Reaction and behaviour of passengers to information in coherence of willingness to pay have been investigated from marketing oriented aspect (Molin, Chorus 2004). In addition, Juhász (2013) examined and assessed the effect of some demand management tools to the travel decision. The results show that provision of public transport information is a significant factor in mode choice.

The passengers' expressed need information have been examined in general with a questionnaire during pre-trip, wayside and on-board phase by Grotenhuis et al. (2007) and then sorted by their importance. Kramers (2014) analysed existing journey planner applications and determined the requirements, the functions on next generation traveller information system.

As walking is the linking element of travel chains, the walking phase influences the quality of the entire travel incredibly. Walking processes can also be controlled and guided by ITS tools (Šimunović et al. 2009). Several studies (Jou et al. 2005; Kenyon, Lyons 2003) have surveyed and described passengers' personal ex-

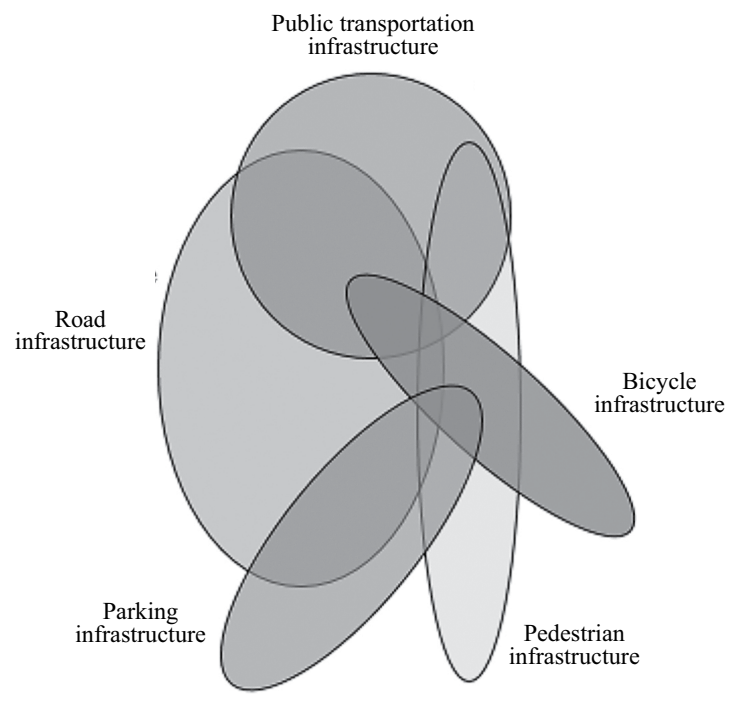

Fig. 1. Connection and proportion of infrastructure elements in passenger transportation network (source: research by the authors) pectations and decision processes, as well as the impact of predicted information on a travellers' habit. It can be stated that travellers take into account a lot of factors (e.g. personal impressions, road geometry, environmental impacts) to choose the appropriate walking route to the public transportation stop or the route between the changing points (Yuen et al. 2013). Travellers usually select their route based on the shortest distance, time or a combination of the two (Ortúzar, Willumsen 2011). Requirements for route planner applications depending on personal characteristics (e.g. age, income, travel motivation) have been summarized in a case study (Cheng 2011).

As the passengers feel the waiting time at the stops twice longer than the passing time in the vehicle (Van Oort, Van Nes 2006), provision of real time information in the waiting phase is especially important. Dziekan, Kottenhoff (2007) specified the relationship between dynamic passenger information in the station and perceived quality. Watkins et al. (2011) ascertained that passengers who used applications with real-time data could reduce their waiting time by $30 \%$, and the real waiting time was perceived by $13 \%$ less than before.

Beside the static data from the service provider (planned timetable) and the dynamic and real-time data from the vehicle (e.g. timetable deviation, current location) the passengers may also be potential information sources. Due to high smartphone penetration, passengers may send data about crowdedness, cleanness or even judge the driver or the service (Ganti et al. 2011) by active cooperation. Information can also be collected from smartphones in a passive way, without active passenger collaboration (e.g. location data using GPS, or cellular, Bluetooth, Wi-Fi, etc. networks) (Bekhor et al. 2013; Szabo et al. 2013).

A detailed inner mapping of transportation or other facilities (e.g. underground/railway stations) is mostly missing from current route planner applications, with the consequence of less accurate results. Several studies engage in data modelling of the inner layout of facilities (Mandloi, Thill 2010; Thill et al. 2011).

The comparison and evaluation of route planners are neither comprehensive nor quantitative in most research papers. Especially, papers regarding to personalization of the routes have been hardly found or other ways of approaches are applied. In many cases, the discussions do not contain more coherences on abstracted level, they remain on level of technical reports. Developers also not really permit accession to the detailed descriptions. Accordingly, our evaluation method described here fill this niche.

Comprehensive personal settings and route planning based on them have only been realized in some applications. First of all the existing route planner applications have been analysed. Then a route plan evaluation method and an algorithm considering user preferences have been developed. The accurate functioning of our algorithm is proven by a mock-up application (with model database) and the results have been illustrated in an example area. 


\section{Comparative Review of Personalization Settings of Existing Journey Planners}

The objective of this research phase was to assess how the existing journey planners are personalized, in order to identify the relevant setting options and build them into our evaluation method.

Personal setting options of existing route planner applications have been examined and then compared by our newly developed situation analysis method. Based on gained experiences, the personalization criteria have been defined and were applied as the basis of the algorithm.

Three Hungarian and seven foreign, well-known and typical route planner applications have been chosen (shown in Fig. 2) to analyse the current situation. The selected applications operate in metropolises and/or regions. Our aims were:

- to select the most personalised application;

- to identify the exemplary settings.

The personal settings of the applications have been collected and categorized. Table 1 shows the categories in the column header and the personal setting options in the cells.

The evaluation method of Esztergár-Kiss and Csiszár (2015) and some elements of the Kesserling method have been considered during the development of our situation analysis method. Since transportation systems and processes are rather complex (they consist of many components and multiple relations), multi-criteria analysis is the most appropriate to compare them (Van Der Laan et al. 1997). The main contribution of the Esztergár-Kiss and Csiszár (2015) method that the framework of the evaluation aspects in order to compare the multimodal journey planners in a quantitative way and to rank them by functional, operational and visualization features has been devised.

The Kesserling method can be used if aspects have same dimensions and their weights are different. In the Kesserling method:

- assessment factors are rated and their weights are determined;

- their sum products are divided by the sum product of the best qualifier values and their weights.

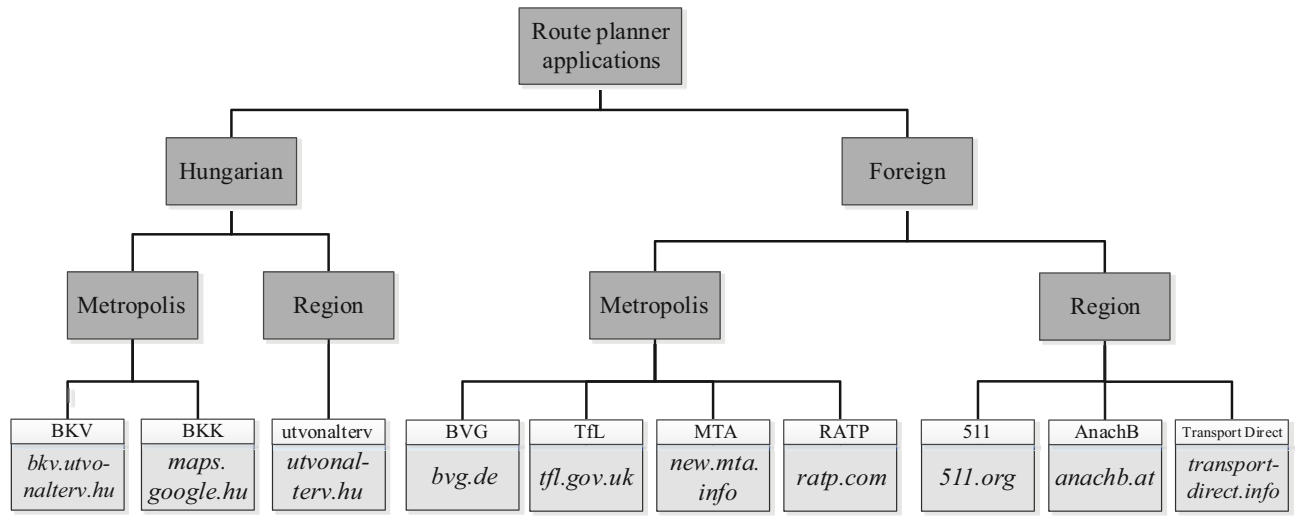

Fig. 2. Grouping of the chosen route planner applications (source: research by the authors)

Table 1. Existing route planner applications' settings and their categories (source: research by the authors)

\begin{tabular}{|c|c|c|c|c|c|c|c|}
\hline \multicolumn{8}{|c|}{ Categories } \\
\hline$s_{1}$ & $s_{2}$ & $s_{3}$ & $s_{4}$ & $s_{5}$ & $s_{6}$ & $s_{7}$ & $s_{8}$ \\
\hline Walking & $\begin{array}{l}\text { Input of } \\
\text { origin and } \\
\text { destination }\end{array}$ & $\begin{array}{c}\text { Blind or } \\
\text { wheel-chaired } \\
\text { traveller }\end{array}$ & $\begin{array}{l}\text { Traveller } \\
\text { with } \\
\text { difficulties }\end{array}$ & $\begin{array}{c}\text { Traveller } \\
\text { with bicycle }\end{array}$ & $\begin{array}{l}\text { Sorting } \\
\text { routes }\end{array}$ & $\begin{array}{l}\text { Choosing } \\
\text { travel } \\
\text { time }\end{array}$ & $\begin{array}{l}\text { Choosing } \\
\text { travel } \\
\text { mode }\end{array}$ \\
\hline \multirow{3}{*}{$\begin{array}{c}s_{11}: \\
\text { walking } \\
\text { speed }\end{array}$} & $\begin{array}{c}s_{21}: \\
\text { address }\end{array}$ & \multirow{2}{*}{$\begin{array}{l}\qquad s_{31}: \\
\text { step free access } \\
\text { to the platform }\end{array}$} & \multirow{2}{*}{$\begin{array}{c}s_{41}: \\
\text { using ramp }\end{array}$} & \multirow{3}{*}{$\begin{array}{l}s_{51}: \\
\text { bicycle storage } \\
\text { in the station }\end{array}$} & $\begin{array}{l}s_{61}: \\
\text { the quickest }\end{array}$ & \multirow{3}{*}{$\begin{array}{c}s_{71}: \\
\text { departure } \\
\text { time }\end{array}$} & \multirow{6}{*}{$\begin{array}{c}\qquad s_{81}: \\
\text { exclusion } \\
\text { or preferring } \\
\text { travel mode }\end{array}$} \\
\hline & & & & & $s_{62}:$ & & \\
\hline & $\begin{array}{l}s_{22}: \\
\text { POI }\end{array}$ & $\begin{array}{c}s_{32}: \\
\text { step free access } \\
\text { to the vehicle }\end{array}$ & $\begin{array}{c}s_{42}: \\
\text { using stairs }\end{array}$ & & $\begin{array}{l}\text { shortest } \\
\text { walking } \\
\text { distance }\end{array}$ & & \\
\hline \multirow{3}{*}{$\begin{array}{c}s_{12}: \\
\text { maximum } \\
\text { walking } \\
\text { distance or } \\
\text { time }\end{array}$} & $\begin{array}{c}s_{23}: \\
\text { public } \\
\text { transportation } \\
\text { stop }\end{array}$ & $\begin{array}{c}s_{33}: \\
\text { staff assistance }\end{array}$ & $\begin{array}{c}s_{43}: \\
\text { using }\end{array}$ & \multirow{3}{*}{$\begin{array}{c}s_{52}: \\
\text { bicycle } \\
\text { carriage on } \\
\text { public vehicle }\end{array}$} & $\begin{array}{c}s_{63}: \\
\text { with fewest } \\
\text { changing }\end{array}$ & \multirow{3}{*}{$\begin{array}{l}\quad s_{72}: \\
\text { arrival time }\end{array}$} & \\
\hline & $\begin{array}{c}s_{24}: \\
\text { coordinates }\end{array}$ & \multirow{2}{*}{$\begin{array}{c}s_{34}: \\
\text { blind guide } \\
\text { system in the } \\
\text { station }\end{array}$} & \multirow{2}{*}{$\begin{array}{c}s_{44}: \\
\text { using } \\
\text { escalator }\end{array}$} & & $\begin{array}{c}s_{64}: \\
\text { without } \\
\text { changing }\end{array}$ & & \\
\hline & $\begin{array}{c}s_{25}: \\
\text { tapping on } \\
\text { map }\end{array}$ & & & & $\begin{array}{l}s_{65}: \\
\text { the cheapest }\end{array}$ & & \\
\hline
\end{tabular}


The benefit of the method is that the degree of deviation from the perfect solution can be clearly ascertained. It is impossible to determine the 'ideal' route planner application due to different personal demands/ expectations and habits. Therefore, our developed situation analysis method is a simplified variant of the Kesserling method, where weight factors are neglected. So the applications are compared not to the 'ideal' one, but to each other.

Steps of our new situation analysis method:

\section{Evaluation of settings}

Each setting $(1-k i)$ is rated on a scale of $0-5$ per application $(1-j)$. Qualifier numbers mainly depend on the following:

- whether the setting option can be selected as a query condition or not;

- ease of use of the setting.

Table 2 shows the aspects of the determination of the qualifier numbers. These aspects are based on personal skills and experiences at the same time, therefore more exact assignment to the numbers cannot be provided.

In the next phase of the research, results of a questionnaire will be also considered.

Table 2. Aspects of the determination of the qualifier numbers (source: research by the authors)

\begin{tabular}{cl}
\hline Value & \multicolumn{1}{c}{ Aspects } \\
\hline 0 & Not available (the setting is missing) \\
\hline 1 & $\begin{array}{l}\text { Not available (the setting is missing, but matter } \\
\text { of the setting is displayed for information purposes } \\
\text { in the case of } s_{3} \text { and } s_{4} \text { categories) }\end{array}$ \\
\hline 2 & $\begin{array}{l}\text { Uneasy to use (not available on the main page, the } \\
\text { number of options is little) }\end{array}$ \\
\hline 3 & $\begin{array}{l}\text { Not so easy to use (not available on the main page, } \\
\text { many setting options) }\end{array}$ \\
\hline 4 & $\begin{array}{l}\text { Easy to use (available on the main page, several } \\
\text { clicks are required, unfolding the words by } \\
\text { characters) }\end{array}$ \\
\hline 5 & $\begin{array}{l}\text { Very easy to use (available on the main page, } \\
\text { many setting options, minimal number of clicks, } \\
\text { unfolding the words by some characters) }\end{array}$ \\
\hline
\end{tabular}

Table 3. Notation of qualifier numbers of settings (source: research by the authors)

\begin{tabular}{|c|c|c|c|c|}
\hline & $a_{1}$ & $a_{2}$ & $\ldots$ & $a_{j}$ \\
\hline$s_{11}$ & $c_{11,1}$ & $c_{11,2}$ & $\ldots$ & $c_{11, j}$ \\
\hline$s_{12}$ & $c_{12,1}$ & $c_{12,2}$ & $\ldots$ & $c_{12, j}$ \\
\hline$s_{21}$ & $c_{21,1}$ & $c_{21,2}$ & $\ldots$ & $c_{21, j}$ \\
\hline$s_{22}$ & $c_{22,1}$ & $c_{22,2}$ & $\ldots$ & $c_{22, j}$ \\
\hline$s_{23}$ & $c_{23,1}$ & $c_{23,2}$ & $\ldots$ & $c_{23, j}$ \\
\hline$s_{24}$ & $c_{24,1}$ & $c_{24,2}$ & $\ldots$ & $c_{24, j}$ \\
\hline$s_{25}$ & $c_{25,1}$ & $c_{25,2}$ & $\ldots$ & $c_{25, j}$ \\
\hline$\ldots$ & $\ldots$ & $\ldots$ & $\ldots$ & $\ldots$ \\
\hline$s_{k i}$ & $c_{k i, 1}$ & $c_{k i, 2}$ & $\ldots$ & $c_{k i, j}$ \\
\hline
\end{tabular}

Table 3 demonstrates the qualifier numbers of settings in general way.

\section{Aggregation and sum of qualifier numbers}

The qualifier numbers for each setting category are calculated as mean values of qualifier numbers of settings (1.1). Table 4 demonstrates the results after aggregation. The determined $c_{k, j}$ qualifier numbers are summarized (1.2) for each application, which finally resulted in $u_{j}$ application qualifier number.

$$
\begin{gathered}
c_{k j}=\frac{\sum_{i} c_{k i, j}}{h_{k}} ; \\
u_{j}=\sum_{k} c_{k, j} .
\end{gathered}
$$

Symbols:

$c_{k, j}$ - mean value of qualifier numbers $c_{k i, j}$ in category $k$ (cells of Table 4);

$c_{k i, j}$ - qualifier number of setting $i$ of category $k$ in application $j(0-5)$ (cells of Table 3);

$h_{k}$ - number of settings in category $k$;

$u_{j}$ - qualifier number of application $j$;

$a_{j}$ - route planner application $j$ (column header of Tables 3-4);

$s_{k i}$ - setting $i$ of category $k$ (row headers of Table 3, which are the same as cells of Table 1);

$s_{k}$ - setting category $k$ (row headers of Table 4 , which are the same as categories of Table 1); the colours show which settings belong to the same category (e.g. settings $s_{11}, s_{12}$ belong to category $s_{1}$ ).

The settings are not weighted.

\section{Ranking}

The applications are sorted in ascending order by qualifier number $u_{j}$.

The results calculated by the developed method are shown in Table 5. Examined applications are located in the columns, symbols of the settings are located in the rows and the qualifier numbers (0-5) are put in the cells. These numbers have been ascertained by the authors' views. We have strived for using the most up-to-date numbers, however due to the ever-changing properties of the application these numbers are subject to change. Most of the applications are being improved, some of them

Table 4. Averaged qualifier numbers by categories (source: research by the authors)

\begin{tabular}{|c|c|c|c|c|}
\hline & $a_{1}$ & $a_{2}$ & $\ldots$ & $a_{j}$ \\
\hline$s_{1}$ & $c_{1,1}$ & $c_{1,2}$ & $\ldots$ & $c_{1, j}$ \\
\hline$s_{2}$ & $c_{2,1}$ & $c_{2,2}$ & $\ldots$ & $c_{2, j}$ \\
\hline$\ldots$ & $\ldots$ & $\ldots$ & $\ldots$ & $\ldots$ \\
\hline$s_{k}$ & $c_{k, 1}$ & $c_{k, 2}$ & $\ldots$ & $c_{k, j}$ \\
\hline$u$ & $u_{1}$ & $u_{2}$ & $\ldots$ & $u_{3}$ \\
\hline
\end{tabular}


Table 5. Application of the developed method - results based on data of 2014 autumn (source: research by the authors)

\begin{tabular}{|c|c|c|c|c|c|c|c|c|c|c|}
\hline \multirow{4}{*}{$\stackrel{\infty}{\mathscr{E}}$} & \multicolumn{3}{|c|}{ Hungarian } & \multicolumn{7}{|c|}{ Foreign } \\
\hline & \multicolumn{2}{|c|}{ Metropolis } & \multirow{2}{*}{\begin{tabular}{|c|} 
Region \\
$\begin{array}{c}\text { utvonalterv. } \\
h u\end{array}$
\end{tabular}} & \multicolumn{4}{|c|}{ Metropolis } & \multicolumn{3}{|c|}{ Region } \\
\hline & $\begin{array}{c}b k v . \\
\text { utvonalterv. } \\
h u\end{array}$ & $\begin{array}{c}\text { maps. } \\
\text { google. } \\
\text { hu }\end{array}$ & & bvg.de & $\begin{array}{c}t f l . \\
g o v . \\
u k\end{array}$ & $\begin{array}{l}\text { new. } \\
\text { mta. } \\
\text { info }\end{array}$ & ratp.com & $\begin{array}{c}511 . \\
\operatorname{org}\end{array}$ & anachb.at & $\begin{array}{c}\text { transport- } \\
\text { direct. } \\
\text { info }\end{array}$ \\
\hline & $a_{1}$ & $a_{2}$ & $a_{3}$ & $a_{4}$ & $a_{5}$ & $a_{6}$ & $a_{7}$ & $a_{8}$ & $a_{9}$ & $a_{10}$ \\
\hline$s_{1}$ & 1.5 & 0 & 0 & 3 & 3 & 1.5 & 0 & 3.5 & 2 & 3 \\
\hline$s_{11}$ & 0 & 0 & 0 & 3 & 3 & 0 & 0 & 3 & 2 & 3 \\
\hline$s_{12}$ & 3 & 0 & 0 & 3 & 3 & 3 & 0 & 4 & 2 & 3 \\
\hline$s_{2}$ & 2.4 & 4.6 & 2.6 & 2.8 & 3,6 & 2.6 & 1.8 & 2.4 & 3 & 1.8 \\
\hline$s_{21}$ & 4 & 5 & 4 & 4 & 5 & 3 & 3 & 3 & 3 & 2 \\
\hline$s_{22}$ & 2 & 5 & 0 & 4 & 3 & 3 & 3 & 3 & 3 & 2 \\
\hline$s_{23}$ & 2 & 4 & 0 & 3 & 4 & 4 & 3 & 3 & 5 & 2 \\
\hline$s_{24}$ & 0 & 4 & 5 & 0 & 3 & 3 & 0 & 0 & 0 & 0 \\
\hline$s_{25}$ & 4 & 5 & 4 & 3 & 3 & 0 & 0 & 3 & 4 & 3 \\
\hline$s_{3}$ & 0.75 & 0 & 0 & 2.25 & 1.5 & 2.5 & 0 & 0 & 0.75 & 2.25 \\
\hline$s_{31}$ & 0 & 0 & 0 & 4 & 3 & 5 & 0 & 0 & 0 & 3 \\
\hline$s_{32}$ & 3 & 0 & 0 & 4 & 3 & 5 & 0 & 0 & 3 & 3 \\
\hline$s_{33}$ & 0 & 0 & 0 & 0 & 0 & 0 & 0 & 0 & 0 & 3 \\
\hline$s_{34}$ & 0 & 0 & 0 & 1 & 0 & 0 & 0 & 0 & 0 & 0 \\
\hline$s_{4}$ & 0 & 0 & 0 & 0.5 & 2 & 0 & 0 & 0 & 2.25 & 0 \\
\hline$s_{41}$ & 0 & 0 & 0 & 0 & 1 & 0 & 0 & 0 & 0 & 0 \\
\hline$s_{42}$ & 0 & 0 & 0 & 0 & 2 & 0 & 0 & 0 & 3 & 0 \\
\hline$s_{43}$ & 0 & 0 & 0 & 1 & 2 & 0 & 0 & 0 & 3 & 0 \\
\hline$s_{44}$ & 0 & 0 & 0 & 1 & 3 & 0 & 0 & 0 & 3 & 0 \\
\hline$s_{5}$ & 0 & 0 & 0 & 0.5 & 3 & 0 & 0 & 0 & 1.5 & 0 \\
\hline$s_{51}$ & 0 & 0 & 0 & 0 & 3 & 0 & 0 & 0 & 2 & 0 \\
\hline$s_{52}$ & 0 & 0 & 0 & 1 & 3 & 0 & 0 & 0 & 1 & 0 \\
\hline$s_{6}$ & 1.8 & 1.2 & 0.6 & 0 & 1.8 & 2.4 & 1.8 & 3 & 1 & 1.2 \\
\hline$s_{61}$ & 3 & 2 & 1 & 0 & 3 & 3 & 3 & 4 & 1 & 0 \\
\hline$s_{62}$ & 3 & 2 & 1 & 0 & 3 & 3 & 3 & 4 & 1 & 0 \\
\hline$s_{63}$ & 3 & 2 & 1 & 0 & 3 & 3 & 3 & 4 & 1 & 3 \\
\hline$s_{64}$ & 0 & 0 & 0 & 0 & 0 & 0 & 0 & 0 & 1 & 3 \\
\hline$s_{65}$ & 0 & 0 & 0 & 0 & 0 & 3 & 0 & 3 & 1 & 0 \\
\hline$s_{7}$ & 2 & 2 & 2.5 & 5 & 4 & 5 & 3 & 4 & 5 & 4 \\
\hline$s_{71}$ & 4 & 2 & 5 & 5 & 4 & 5 & 3 & 4 & 5 & 4 \\
\hline$s_{72}$ & 0 & 2 & 0 & 5 & 4 & 5 & 3 & 4 & 5 & 4 \\
\hline$s_{8}$ & 2 & 3 & 0 & 3 & 3 & 5 & 2 & 3 & 3 & 3 \\
\hline$s_{81}$ & 2 & 3 & 0 & 3 & 3 & 5 & 2 & 3 & 3 & 3 \\
\hline$\overline{u_{j}}$ & 10.45 & 10.80 & 5.70 & 17.05 & 21.90 & 19.00 & 8.60 & 15.90 & 18.50 & 15.25 \\
\hline
\end{tabular}

Note: ${ }^{*}$ the application is not available (30 September 2014$)$.

declines or are not available any more. The determined categories with their mean values are highlighted in light blue in the table. The application qualifier numbers $u_{j}$ are calculated in the last row and highlighted in dark blue.

The highest scores were awarded to route planner applications TfL, MTA and AnachB due to the number of personalised settings they contain, mainly for handicapped people. Among the examined Hungarian applications, (BKK) maps.google.hu achieved the best result mainly due to its ease of use. Applications with less than 15 points just contain origin, destination and date of travel settings.
By our analysis method the properties of the applications can be compared to each other, not to an ideal one. In this way 'the best' application is better only than the examined other ones, as the range of the settings depends on the chosen applications. There are several exemplary and unique partial solutions in the examined applications. For example, setting origin and destination with word fragment only, information about additional services, settings and queries aiding handicapped people, information about the barriers (stairs, escalators, etc.). We strived to include these exemplary settings to our developed algorithm. The route options are estimat- 
ed and compared by the properties of the first stop, and the walking way there (from origin point to stop). In the next sections the algorithm is discussed step by step.

\section{Route Plan Evaluation Method}

The evaluation method is based on one hand on the physical properties of the routes and on the other hand on the evaluation criteria. The evaluation criteria of personalization have been determined by the exemplary settings of the existing route planner applications and our own experiences.
Our devised route plan evaluation method as well as the algorithm and the mock-up application (with model database) use the following data sources:

- detailed Geographic Information System (GIS);

- data from the exterior route planner applications;

- personal preferences (Tables 6-7).

The algorithm evaluates predefined routes, therefore so-called exterior route planner applications are required, which plan the routes as detailed as possible and consider all combinations of the walking and travel phases (e.g. distinguishing the pavements on the two

Table 6. Personalised setting options in the access-walking phase (source: research by the authors)

\begin{tabular}{|c|c|c|c|c|c|}
\hline \multirow{2}{*}{ Travel phase } & \multicolumn{3}{|c|}{ Settings } & \multirow{2}{*}{ Options } & \multirow{2}{*}{ Values } \\
\hline & Category & Name & Symbol & & \\
\hline \multirow{40}{*}{ 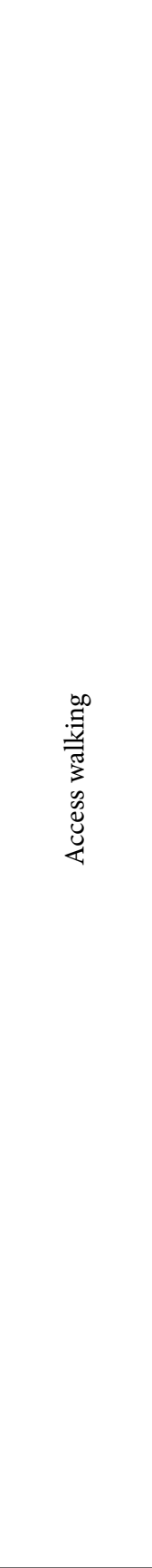 } & \multirow{10}{*}{ 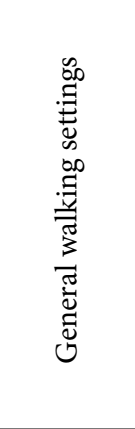 } & \multirow[t]{5}{*}{ 1. Walking speed $[\mathrm{m} / \mathrm{s}]$} & \multirow{5}{*}{$x_{1}$} & very fast & 1.67 \\
\hline & & & & fast & 1.39 \\
\hline & & & & average & 1.11 \\
\hline & & & & slow & 0.83 \\
\hline & & & & very slow & 0.55 \\
\hline & & \multirow{5}{*}{$\begin{array}{l}\text { 2. Maximum walking distance }[\mathrm{m}] \\
\text { (Disqualifying criterion, if the sum of } \\
\text { the actual walking distances is higher } \\
\text { than } x_{2} \text { ) }\end{array}$} & \multirow{5}{*}{$x_{2}$} & 200 & 200 \\
\hline & & & & 400 & 400 \\
\hline & & & & 600 & 600 \\
\hline & & & & 800 & 800 \\
\hline & & & & 1000 & 1000 \\
\hline & \multirow{3}{*}{\multicolumn{2}{|c|}{ 3. Uphill slope/downhill slope }} & \multirow{3}{*}{$x_{3}$} & indifferent & 1 \\
\hline & & & & disturbing & 1.1 \\
\hline & & & & disqualifying & 1000 \\
\hline & \multirow{11}{*}{ 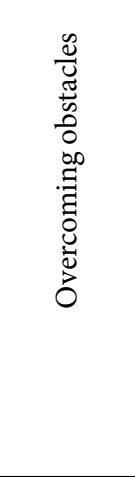 } & \multirow[t]{3}{*}{ 4. Stairs } & \multirow{3}{*}{$x_{4}$} & indifferent & 1 \\
\hline & & & & disturbing & 1.15 \\
\hline & & & & disqualifying & 1000 \\
\hline & & \multirow[t]{3}{*}{ 5. Escalator } & \multirow{3}{*}{$x_{5}$} & indifferent & 1 \\
\hline & & & & disturbing & 1.1 \\
\hline & & & & disqualifying & 1000 \\
\hline & & \multirow[t]{3}{*}{ 6. Elevator } & \multirow{3}{*}{$x_{6}$} & indifferent & 1 \\
\hline & & & & disturbing & 1.14 \\
\hline & & & & disqualifying & 1000 \\
\hline & & \multirow[t]{2}{*}{ 7. Ramp } & \multirow{2}{*}{$x_{7}$} & indifferent & 1 \\
\hline & & & & disturbing & 1.05 \\
\hline & \multirow{9}{*}{ 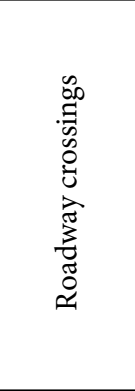 } & \multirow[t]{2}{*}{ 8. Pedestrian crossing with traffic light } & \multirow{2}{*}{$x_{8}$} & indifferent & 1 \\
\hline & & & & disturbing & 1.03 \\
\hline & & \multirow{2}{*}{$\begin{array}{l}\text { 9. Pedestrian crossing without traffic } \\
\text { light }\end{array}$} & & indifferent & 1 \\
\hline & & & $x_{9}$ & disturbing & 1.05 \\
\hline & & 10. Intersection without pedestrian & & indifferent & 1 \\
\hline & & crossing & ${ }^{x} 10$ & disturbing & 1.06 \\
\hline & & 11. Lack of sunken shoulder in the & & indifferent & 1 \\
\hline & & intersection & $x_{11}$ & disturbing & 1.02 \\
\hline & & & & disqualifying & 1000 \\
\hline & & 12. Lack of blind guide system & & indifferent & 1 \\
\hline & $\stackrel{0}{0}$ & (in passenger facilities) & $x_{12}$ & disturbing & 1.01 \\
\hline & $\stackrel{\pi}{\pi}$ & & & disqualifying & 1000 \\
\hline & 惫 & 13. Lack of step free access to the & & indifferent & 1 \\
\hline & $\stackrel{\mathscr{U}}{=}$ & platform & $x_{13}$ & disqualifying & 1000 \\
\hline & 0 & 14. Lack of staff assistance & & indifferent & 1 \\
\hline & & (in passenger facilities) & $x_{14}$ & disqualifying & 1000 \\
\hline
\end{tabular}


Table 7. Personalised setting options in the journey (waiting and travelling) phase (source: research by the authors)

\begin{tabular}{|c|c|c|c|c|c|}
\hline \multirow{2}{*}{ Travel phase } & \multicolumn{3}{|c|}{ Settings } & \multirow{2}{*}{ Options } & \multirow{2}{*}{ Values } \\
\hline & No & Name & Symbol & & \\
\hline \multirow{23}{*}{ 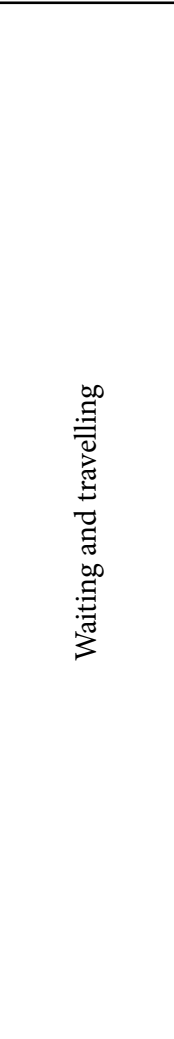 } & \multirow{2}{*}{\multicolumn{2}{|c|}{$\begin{array}{l}\text { 15. Lack of passenger information system in the } \\
\text { station }\end{array}$}} & \multirow{2}{*}{$x_{15}$} & indifferent & 1 \\
\hline & & & & disturbing & 1.08 \\
\hline & \multirow{2}{*}{\multicolumn{2}{|c|}{ 16. Lack of comfort equipment in the station }} & \multirow{2}{*}{$x_{16}$} & indifferent & 1 \\
\hline & & & & disturbing & 1.11 \\
\hline & \multirow{4}{*}{\multicolumn{2}{|c|}{$\begin{array}{l}\text { 17. Maximum waiting time in the station for ideal } \\
\text { vehicle }[\mathrm{s} \text { ] }\end{array}$}} & \multirow{4}{*}{$x_{17}$} & $0 \mathrm{~min}$ & 0 \\
\hline & & & & $5 \mathrm{~min}$ & 300 \\
\hline & & & & $10 \mathrm{~min}$ & 600 \\
\hline & & & & $15 \mathrm{~min}$ & 900 \\
\hline & \multirow{2}{*}{\multicolumn{2}{|c|}{ 18. Lack of step free access to the vehicle }} & \multirow{2}{*}{$x_{18}$} & indifferent & 1 \\
\hline & & & & disturbing & 1.05 \\
\hline & \multirow{2}{*}{\multicolumn{2}{|c|}{ 19. Lack of air-condition in the vehicle }} & \multirow{2}{*}{$x_{19}$} & indifferent & 1 \\
\hline & & & & disturbing & 1.03 \\
\hline & \multirow{2}{*}{\multicolumn{2}{|c|}{ 20. Lack of Wi-Fi in the vehicle }} & \multirow{2}{*}{$x_{20}$} & indifferent & 1 \\
\hline & & & & disturbing & 1.02 \\
\hline & \multirow{2}{*}{\multicolumn{2}{|c|}{ 21. Lack of wheelchair accessible vehicles }} & \multirow{2}{*}{$x_{21}$} & indifferent & 1 \\
\hline & & & & disqualifying & 1000 \\
\hline & \multirow{4}{*}{\multicolumn{2}{|c|}{ 22. Exclusion of transportation mode }} & \multirow{4}{*}{$x_{22}$} & bus & 1000 \\
\hline & & & & tram & 1000 \\
\hline & & & & underground & 1000 \\
\hline & & & & $\ldots$ & $\ldots$ \\
\hline & \multirow{3}{*}{\multicolumn{2}{|c|}{ 23. Lack of direct journey }} & \multirow{3}{*}{$x_{23}$} & indifferent & 1 \\
\hline & & & & disturbing & 1.4 \\
\hline & & & & disqualifying & 1000 \\
\hline
\end{tabular}

sides of the road). If the exterior route planner provides routes based on real-time data, this data is also used in the entire evaluation method. It does not influence the calculation.

\subsection{Calculation Method}

Final result of operation of our algorithm is a qualifier number. This number is a time-based resistance value $r$, which refers to the perceived time. Its value depends on the properties of the routes and the personal settings. The settings have been sorted according to the travel phases:

I. access walking from the origin point to the first stop;

II. waiting and travelling (possibly with transfer);

III. egress walking from the last stop to the destination.

Qualifier number of the route $n$ (depending on users' preferences) is the sum of time values regarding the three phases of travel (2.1):

$$
r^{n}=t^{n, \mathrm{I}}+t^{n, \mathrm{II}}+t^{n, \mathrm{III}} .
$$

Marking $n$ is disregarded in the further formulas.

The personal settings can be adjusted in the following ways:

- selecting from values (from set of finite element),

- determining the importance of the setting criteria ('indifferent'/'disturbing'/'disqualifying').

Identification of importance regarding personal setting criteria has been discussed in several papers (Dule- ba et al. 2012; Sivilevičius, Maskeliūnaitè, 2010). Analytic Hierarchy Process (AHP) methodology based on the pair wise criteria comparison is often used to determine the significances (weights). In our case, numerical values have been assigned to each setting options taking into account the results of the scientific literature and our own experiences. The determination of these values requires a detailed questioning of the travellers. As it has still not been performed, the values are provided only for demonstration purposes. The questionnaire may prove or disprove our assumptions, and the values can be modified by the results. Consideration of disturbing properties is less sophisticated. If the property is very disturbing, the user sets disqualification otherwise 'accepts' our values. There is still no way for modification of the values by the users, but it is intended to build into the mock-up application in the future. Correctness of the algorithm can be further improved by tuning these values up.

Setting options of the access and egress walking phases are the same. Walking options are set at once, for any other walking phase the algorithm calculates with these values.

\section{Access walking}

Access phase covers walking from the origin point to the platform of the first stop. It can be calculated based on the perceived time (2.2): 


$$
t^{\mathrm{I}}=\left(t_{w}^{\mathrm{I}}+t_{o}^{\mathrm{I}}+t_{c}^{\mathrm{I}}\right) \cdot x_{d}^{\mathrm{I}},
$$

where: $t_{w}^{\mathrm{I}}$ - walking time on flat surface; on the street or in passenger facilities (e.g. stations, stops) $[s] ; t_{o}^{\mathrm{I}}-$ perceived time of overcoming obstacles $[s] ; t_{c}^{\mathrm{I}}$ - perceived time at roadway crossings $[s] ; x_{d}^{\mathrm{I}}-$ correction factor for disabled travellers.

Values of variables $\left(x_{p}\right.$, where $\left.p=1 \ldots 14\right)$ regarding personalised settings in the walking phase are shown in Table 6. Default values are highlighted with a yellow background. The walking speed can be selected from five options ('very slow', 'slow', 'average', 'fast', 'very fast'). Assigned speed values are between $0.55-1.67 \mathrm{~m} / \mathrm{s}$ $(2-6 \mathrm{~km} / \mathrm{h})$. The maximum acceptable access and egress walking distance can be also selected from five options $(200,400,600,800,1000 \mathrm{~m})$. In case of the remaining settings the user may determine their importance ('indi fferent'/'disturbing'/'disqualifying'). Values regarding the setting options (preferences) have been determined as follows:

- 'indifferent': these values are 1 , so the user's preference does not influence the perceived time value;

- 'disturbing': these values are close to 1, slightly influencing the perceived time value;

- 'disqualifying': these values are 1000, practically disqualifying the route, because the qualifier number becomes too large.

$t_{w}^{\mathrm{I}}$ walking time on flat surface can be calculated as follows (2.3):

$$
t_{w}^{\mathrm{I}}=\frac{d_{1}+d_{2}}{x_{1}},
$$

where: $d_{1}$ - walking distance on flat surface from origin point to platform/entrance of passenger facilities [m]; $d_{2}$ - walking distance on flat surface inside the passenger facilities $[\mathrm{m}] ; x_{1}-$ walking speed $[\mathrm{m} / \mathrm{s}]$.

$t_{o}^{\mathrm{I}}$ perceived time of overcoming obstacles $[\mathrm{s}]$ on the walking way can be broken down into components based on (2.4):

$$
t_{o}^{\mathrm{I}}=\sum_{l=3}^{7} t_{l},
$$

where the elements are resistance values of: $t_{3}$ - uphill slope/downhill slope; $t_{4}$ - stairs; $t_{5}$ - escalator; $t_{6}$ - elevator; $t_{7}-$ ramp.

Resistances $t_{3} \ldots t_{7}$ depend on the length, steepness, operational speed of the hindrances and the user preferences $\left(x_{3} \ldots x_{7}\right)$.

Summation in the formulas regards to each element of the network. (Walking upwards and downwards are not distinguished.)

$t_{3}$ resistance of uphill slope/downhill slope (2.4.1), we assumed constant $20 \%$ decrease of the walking speed irrespectively of the value of the steepness:

$$
t_{3}=\left(\sum \frac{(e+1) \cdot d_{3}}{x_{1} \cdot 0.8}\right) \cdot x_{3},
$$

where: $e$ - steepness [\%]; $d_{3}$ - length of slope [m]; $x_{1}-$ walking speed $[\mathrm{m} / \mathrm{s}] ; x_{3}-$ correction factor for walking on a slope. $t_{4}$ resistance of stairs (2.4.2), we assumed constant $25 \%$ decrease of the walking speed irrespectively of the length of the stairs:

$$
t_{4}=\left(\frac{\sum d_{4}}{x_{1} \cdot 0.75}\right) \cdot x_{4},
$$

where: $d_{4}$ - length of stairs $[\mathrm{m}] ; x_{1}-$ walking speed $[\mathrm{m} / \mathrm{s}]$; $x_{4}$ - correction factor for walking on stairs.

$t_{5}$ resistance of escalator (2.4.3):

$$
t_{5}=\left(\sum \frac{d_{5}}{v_{5}}\right) \cdot x_{5},
$$

where: $d_{5}$ - length of escalator $[\mathrm{m}] ; v_{5}$ - escalator speed $[\mathrm{m} / \mathrm{s}] ; x_{5}$ - correction factor for using escalator.

$t_{6}$ resistance of elevator (2.4.4):

$$
t_{6}=\left(\sum\left(\frac{d_{6}}{v_{6}}+t_{w 6}\right)\right) \cdot x_{6},
$$

where: $d_{6}$ - height of elevator $[\mathrm{m}] ; v_{6}$ - elevator speed $[\mathrm{m} / \mathrm{s}] ; t_{w 6}$ - average waiting time for the elevator [s], it is determined for each elevator; $x_{6}$ - correction factor for using elevator.

$t_{7}$ resistance of ramp (2.4.5), we assumed constant $10 \%$ decrease of the walking speed irrespectively of the value of the steepness:

$$
t_{7}=\left(\sum \frac{(e+1) \cdot d_{7}}{x_{1} \cdot 0.9}\right) \cdot x_{7},
$$

where: $e$ - steepness [\%]; $d_{7}$ - length of ramp [m]; $x_{1}-$ walking speed $[\mathrm{m} / \mathrm{s}] ; x_{7}-$ correction factor for walking on a ramp.

The determination of the current average decreases of the walking speed requires more detailed measurements.

$t_{c}^{\mathrm{I}}$ perceived time at roadway crossings $[\mathrm{s}]$ is calculated as follows (2.5):

$$
t_{c}^{I}=\left(t_{8}+t_{9}+t_{10}\right) \cdot x_{11},
$$

where: $t_{8}$ - resistance value of pedestrian crossing with traffic light; $t_{9}$ - resistance value of pedestrian crossing without traffic light; $t_{10}$ - resistance value of intersection without pedestrian crossing; $x_{11}$ - correction factor for lack of sunken shoulder in the intersection (it is set by the user).

Resistances $t_{8} \ldots t_{10}$ depend on the number of the intersections, the average waiting time, the correction factor of the perceived safety and the user preferences $\left(x_{8} \ldots x_{10}\right)$.

Summation in the formulas regards to each element of the network. The waiting times are determined for each type of crossings.

$t_{8}$ resistance value of pedestrian crossing with traffic light (2.5.1):

$$
t_{8}=\sum t_{w 8} \cdot a_{8} \cdot x_{8}
$$

where: $t_{w 8}$ - average waiting time $[\mathrm{s}] ; a_{8}-$ correction factor of the perceived safety $\left(a_{8}-0.85\right) ; x_{8}-$ correction factor for using pedestrian crossing with traffic light. 
$t_{9}$ resistance value of pedestrian crossing without traffic light (2.5.2):

$$
t_{9}=\sum t_{w 9} \cdot a_{9} \cdot x_{9}
$$

where: $t_{w 9}$ - average waiting time [s]; $a_{9}$ - correction factor of the perceived safety $\left(a_{9}-0.95\right) ; x_{9}$ - correction factor for using pedestrian crossing with traffic light.

$t_{10}$ resistance value of intersection without pedestrian crossing (2.5.3):

$$
t_{10}=\sum t_{w 10} \cdot a_{10} \cdot x_{10},
$$

where: $t_{w 10}$ - average waiting time [s]; $a_{10}$ - correction factor of the perceived safety $\left(a_{10}-1.05\right) ; x_{10}$ - correction factor for using pedestrian crossing with traffic light.

The determination of the correction factors of the perceived safety requires a more detailed questioning of the travellers.

$x_{d}^{\mathrm{I}}$ correction factor for disabled travellers is calculated as follows (2.6):

$$
x_{d}^{\mathrm{I}}=\prod_{p=12}^{14} x_{p} .
$$

\section{Waiting and travelling}

The algorithm also takes into consideration the personalised settings of the processes after the walking phase. In this way the perceived waiting time at the stops, the perceived travelling time in the vehicle and the effects of the transfers can be calculated by formula (2.7). Table 7 shows the personal setting options.

$$
t^{\mathrm{II}}=t_{\text {wait }}(t) \cdot x_{s}+t_{t} \cdot x_{v}+Y,
$$

where: $t_{\text {wait }}(t)$ - waiting time at the stop/platform [s]; $x_{s}$ - correction factor, which influences the perceived waiting time at stop; $t_{t}$ - vehicle journey time (static data from the timetable) [s]; $x_{v}$ - vehicle qualifier correction factor; $Y$ - correction factor regarding possible transfers.

$t_{\text {wait }}(t)$ waiting time at the stop/platform [s]. Elapsed time from step to the platform until vehicle arrival time. This is a dynamic variable because it depends on the actual arrival times of both passenger and vehicle.

$x_{s}$ correction factor, which is calculated as follows (2.8):

$$
x_{s}=\prod_{p=15}^{16} x_{p} \text {. }
$$

Lack of passenger information system: an electronic display with the planned/actual schedule times is missing. Lack of comfort equipment: clean and convenient seat is not available. (2.9):

$x_{v}$ correction factor, which is calculated as follows

$$
x_{v}=\prod_{p=17}^{22} x_{p} .
$$

where: $x_{17}$ is the maximum waiting time at the stop (in the station) for an ideal vehicle [s], which depends on the attributes of the arriving vehicle and the user prefer- ences. $x_{17}$ is only relevant, if the user modifies any default value ('indifferent') in settings $x_{18} \ldots x_{21}$. For example, if the first arriving vehicle is not appropriate but the next one is ideal, furthermore the waiting time is less than the tolerable time limit $\left(x_{17}\right)$, then the second one is chosen. Interdependences of settings $x_{18} \ldots x_{21}$ on $x_{17}$ are illustrated by arrow. Selection of options of the settings are arbitrary; they are considered independently during the queries. However, setting $x_{17}$ and settings $x_{18} \ldots x_{21}$ interact, which is realized in the algorithm as a logical conditional evaluation (see procedure (9) in Fig. 3).

$Y$ correction factor regarding possible transfers. If there is any transfer, the algorithm repeats the previous steps (walking, waiting, travelling). If the travel is direct, $Y=0$. If the travel is indirect, $Y$ is calculated in the following way (2.10):

$$
Y=\sum_{m=0}^{g}\left(t^{I, m}+t_{\text {wait }}^{m}(t) \cdot x_{s}^{m}+t_{t}^{m} \cdot x_{v}^{m}\right) \cdot x_{23},
$$

where: $g$ - number of transfers; $t^{I, m}$ - transfer $m$ walking time based on formula (2.2); $t_{\text {wait }}^{m}$ - transfer $m$ waiting time at the stop/platform $[s] ; x_{s}^{m}$ - transfer $m$ correction factor, which influences the perceived waiting time; $t_{t}^{m}$ - transfer $m$ vehicle journey time (static data from the timetable) [s]; $x_{v}^{m}$ - transfer $m$ vehicle qualifier correction factor; $x_{23}$ - correction factor regarding lack of direct journey.

\section{Egress}

The settings of the egress walking phase are the same as they in the access walking phase.

\subsection{Algorithm}

The availability of detailed data of travel phases, provided by the exterior route planner applications, was supposed at the development of the algorithm. The route planning requires integrated and updated timetable databases. The route evaluation requires regularly maintained, detailed and accurate geographic data. If the updated geographic database is not available, extensive data collection technologies should be applied (e.g. geodesic measurements, laser scanning). Operation of the algorithm is represented in Figs 3-4. Initialization and calculation procedures, their logical order as well as the calculations organized into cycles are detailed in Fig. 3.

\section{Specification of journey properties}

After input of origin, destination and travel date (1), levels of the personal settings can be selected. Three setting levels have been determined:

- Without setting (2): routes are evaluated by default values.

- Group setting (3): one of the predefined typical passenger groups (motivations) can be selected; the groups are student, worker, pensioner, tourist and disabled person. Default values were determined based on statistical data to each group.

- Every detail (4): each setting is adjusted by the user. 


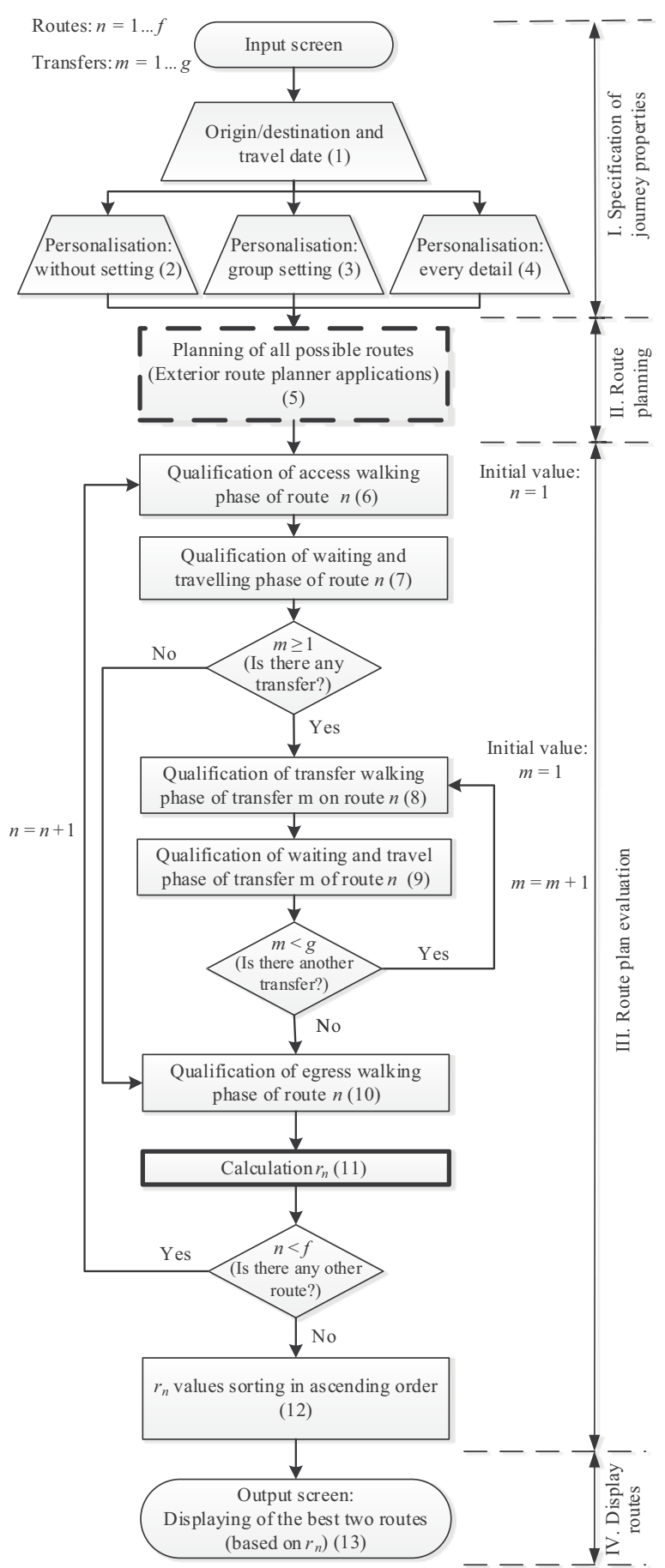

Fig. 3. Operational flowchart of algorithm (source: research by the authors)

\section{Route planning}

Conventional 'exterior' route planner applications determine all possible routes in details from the origin to the destination (5). Only the public transportation stops within a 1000 meter radius of the origin point are considered.

\section{Route plan evaluation}

The routes are evaluated with consideration to both the exact physical properties of the routes and the user preferences (settings). The routes have several attributes (length of stairs, number of pedestrian crossings with traffic light, etc.), to which the personalised values are assigned. In the course of the qualifier number calculation the following phases are evaluated: access walking (6), waiting and travelling (7), transfer walking (8) (if it is required), next waiting and travelling (9) and finally (if there is not any other transfer) egress walking (10). Route qualifier number $r_{n}$ is calculated as a sum of values from each phase (11). The routes are sorted in ascending order by value $r_{n}(12)$.

\section{Display routes}

The best two routes are displayed in detail for the user on own info-communication devices (e.g. smart phone) (13).

In the next steps of the research we intend to combine the exterior route planner and our evaluation method and in this way to create the so called integrated route planner application. By the integration of the two functions the search space can be filtered by the personalised settings, so the effectiveness of the searching is improved, the required time is reduced and better solutions are to be achieved.

\section{Example Area}

The objective was to illustrate the benefits the algorithm has over existing journey planners by experiments. The results of our algorithm have been compared with results of existing route planner applications. Attributes that are available in most of the applications have been examined.

Exclusion of transportation modes, preference of step free journey and selection by qualification of the entire route (the quickest route, routes with fewest changes, routes with less walking) options can be generally found

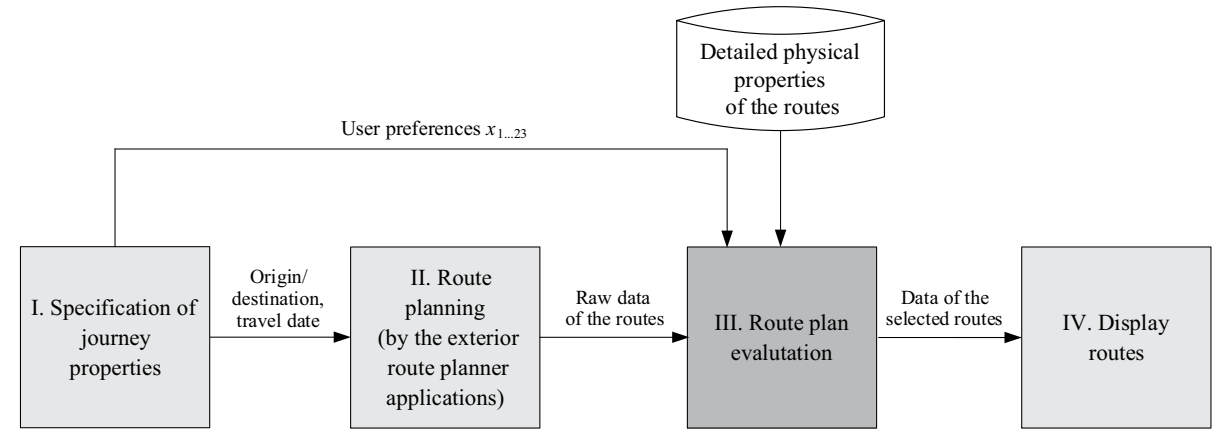

Fig. 4. Simplified operational flowchart of algorithm (source: research by the authors) 
in the existing applications; so they are comparable. We have chosen an example area, where all kind of hindrances are available and the created routes are various both in lines and in vehicle types.

The results of our algorithm were compared to the results of the Hungarian applications (mentioned in section 1). The example area is located in Budapest, Hungary. Public travel options between Budapest University of Technology and Economics, Building 'St' and Main Railway Station/Keleti pályaudvar have been analysed based on data from autumn 2013. The exact time of departure was 16:00 12.11.2013.

The routes have been determined by analysis (partially in manual way) of all stops around the origin point and all public transportation services from the certain points. The determined route options are shown in Fig. 5. Beside the route options explained in columns $\mathrm{B}, \mathrm{C}, \mathrm{D}$ of Table 8 all the other journey options (combinations of the modes/lines with one transfer) were the inputs of the evaluation algorithm.

Then the detailed attributes were added to these routes. The properties of the routes have been revealed by site visits and measurements (e.g. length of stairs, length of slopes, steepness). The algorithm (re)calculates the expected journey times using user preferences and detailed GIS data.

The routes created by the following personalised settings have been compared:

1. the quickest route;

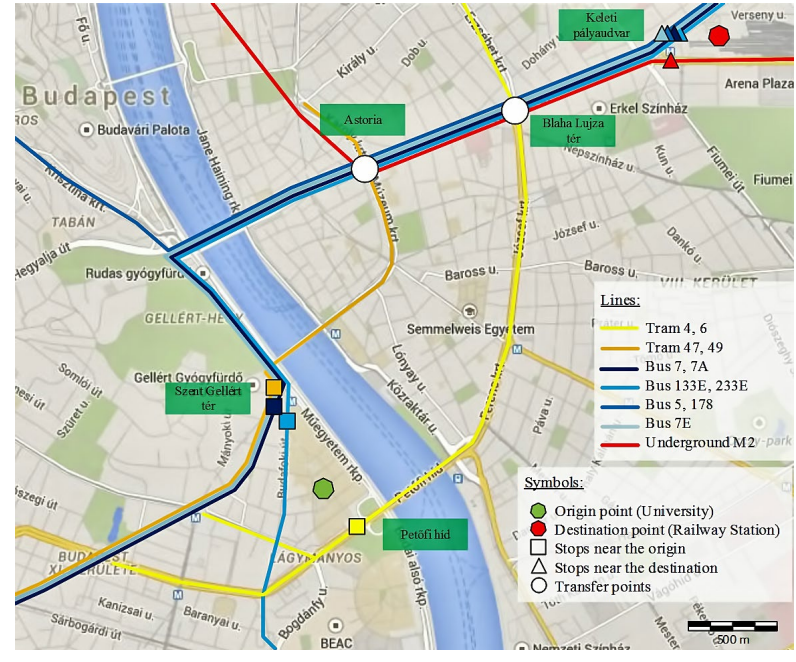

Fig. 5. The example area (source: research by the authors)

2. routes with fewest changes;

3. routes with less walking distance (the maximum walking distance was 400 meter);

4. bus excluded routes;

5. step free journey.

Table 8 summarizes the most relevant data (e.g. total travel time, used lines and their boarding stops) of the routes by applications (column header) and by settings (row header). The most realistic results are indicated by yellow background.

Table 8. Results of queries per applications (source: research by the authors)

\begin{tabular}{ccccc}
\hline $\mathrm{A}$ & $\mathrm{B}$ & $\mathrm{C}$ & $\mathrm{D}$ & Advantages of algorithm \\
performance
\end{tabular}

\begin{tabular}{|c|c|c|c|c|c|c|}
\hline 1. & $\begin{array}{l}\text { The } \\
\text { quickest } \\
\text { route }\end{array}$ & $\begin{array}{c}21 \text { min } \\
\text { Tram } 6 \\
\text { (Petőfi híd) }+ \\
\text { bus 7E } \\
\text { (Blaha Lujza tér) }\end{array}$ & $\begin{array}{c}\mathbf{2 8} \text { min } \\
\text { Bus } 7 \\
\text { (Szent Gellért tér) }\end{array}$ & $\begin{array}{c}23 \text { min } \\
\text { Bus 233E } \\
\text { (Szent Gellért tér) }\end{array}$ & $\begin{array}{c}\mathbf{2 3} \text { min } \\
\text { Tram } 6 \\
\text { (Petöfi híd) }+ \\
\text { underground M2 } \\
\text { (Blaha Lujza tér) }\end{array}$ & $\begin{array}{l}\text { Less walking distance and time } \\
\text { because the detailed mapping } \\
\text { of internal areas (additional } \\
\text { paths in university) }\end{array}$ \\
\hline 2. & $\begin{array}{l}\text { Routes } \\
\text { with } \\
\text { fewest } \\
\text { changes }\end{array}$ & $\begin{array}{c}27 \text { min } \\
\text { Bus 133E } \\
\text { (Szent Gellért tér) }\end{array}$ & $\begin{array}{c}\mathbf{2 8} \mathbf{~ m i n} \\
\text { Bus } 7 \\
\text { (Szent Gellért tér) }\end{array}$ & $\begin{array}{c}\mathbf{2 3} \text { min } \\
\text { Bus 233E } \\
\text { (Szent Gellért tér) }\end{array}$ & $\begin{array}{c}31 \text { min } \\
\text { Bus } 7 \\
\text { (Szent Gellért tér) }\end{array}$ & $\begin{array}{l}\text { The slower default walking } \\
\text { speed is more realistic, despite } \\
\text { of missing the earlier departure } \\
\text { (vs. variant C) }\end{array}$ \\
\hline & $\begin{array}{l}\text { Routes } \\
\text { with less } \\
\text { walking }\end{array}$ & $\begin{array}{c}21 \text { min } \\
\text { Tram } 6 \\
\text { (Petőfi híd) }+ \\
\text { bus } 7 \mathrm{E} \\
\text { (Blaha Lujza tér) }\end{array}$ & $\begin{array}{c}\mathbf{2 8} \mathbf{~ m i n} \\
\text { Bus 133E } \\
\text { (Szent Gellért tér) }\end{array}$ & $\begin{array}{c}\mathbf{2 5} \text { min } \\
\text { Tram } 6 \\
\text { (Petőfi híd) }+ \\
\text { underground M2 } \\
\text { (Blaha Lujza tér) }\end{array}$ & $\begin{array}{c}\mathbf{2 5} \text { min } \\
\text { Tram } 6 \\
\text { (Petőfi híd) }+ \\
\text { underground M2 } \\
\text { (Blaha Lujza tér) }\end{array}$ & $\begin{array}{l}\text { Less walking distance and time } \\
\text { because the detailed mapping } \\
\text { of internal areas (additional } \\
\text { paths in university) }\end{array}$ \\
\hline 4. & $\begin{array}{l}\text { Bus } \\
\text { excluded } \\
\text { routes }\end{array}$ & $\begin{array}{c}31 \text { min } \\
\text { Tram } 47 \\
\text { (Gárdonyi tér) + } \\
\text { underground M2 } \\
\text { (Astoria) } \\
\end{array}$ & $\begin{array}{c}31 \text { min } \\
\text { Tram } 6 \\
\text { (Petöfi híd) + } \\
\text { underground M2 } \\
\text { (Blaha Lujza tér) }\end{array}$ & $\begin{array}{c}25 \text { min } \\
\text { Tram } 6 \\
\text { (Petöfi híd) }+ \\
\text { underground M2 } \\
\text { (Blaha Lujza tér) }\end{array}$ & No such & $\begin{array}{l}\text { The longer journey time } \\
\text { is more realistic, because } \\
\text { walking time in the indoor } \\
\text { facilities (underground) is also } \\
\text { considered (vs. variant C) }\end{array}$ \\
\hline & $\begin{array}{l}\text { Step free } \\
\text { journey }\end{array}$ & $\begin{array}{c}\mathbf{4 8} \mathbf{~ m i n} \\
\text { Bus 133E } \\
\text { (Szent Gellért tér) }\end{array}$ & $\begin{array}{c}\mathbf{4 4} \text { min } \\
\text { Bus } 7 \\
\text { (Szent Gellért tér) }\end{array}$ & No such option & No such option & $\begin{array}{l}\text { The longer walking distance and } \\
\text { time is more realistic because } \\
\text { all steps (e.g.: not sunken } \\
\text { shoulder in the intersection) are } \\
\text { considered (vs. variant B) }\end{array}$ \\
\hline
\end{tabular}

Note: (Petőfi híd) - name of the boarding stop. 
The weaknesses of the existing applications have been revealed in the following way:

- analysis of setting options of the applications;

- analysis of data elements and their coherences in the route options as well as details of routes on maps;

- deductions from the results to the operational processes and the used data.

The imperfections of the applications are:

- lack of description (mapping) of internal areas (e.g. possible walking movements within the university);

- ignoring walking time in the indoor facilities (e.g. underground, railway station) and escalator time;

- using different walking speeds for calculating walking time.

To interpret the first imperfection, A3 option contains less walking than the others (B3, C3 and D3) because the algorithm calculates the exact distances within the campus area, whereas the others use only the nearest public roads.

A1 and D1 cells interpret the second imperfection. In the D1 option in the second travel phase the underground M2 is preferred, because it is quick, whereas the escalator times both downwards and upwards are not taken into consideration.

The utility of our algorithm was illustrated through the more realistic journey times calculated when compared with those produced by the external planners. In the majority of cases, the time results were the lowest one, despite the inclusion of extra time elements (e.g. loss of time by the pedestrian crossing, deceleration because of an uphill slope). In some cases, the longer travel time calculated by our algorithm can be considered as better one, because it is more realistic value thanks to the detailed mapping.

The algorithm demonstrated that travel on the surface is more favourable and requires less time on a one or two stop long trip, than the parallel underground travel. This can be also observed in the example area, where several bus lines and an underground line run in parallel (Astoria - Blaha Lujza square - Main Railway Station/Keleti pályaudvar). The algorithm suggests travelling by underground only in the case, that travelling by bus is set as 'disqualifying. The comparison also indicated that results (routes, times) of our algorithm are much closer to the reality, than the results of the existing applications. Since the input data of our algorithm is exact (e.g. own measurements) it can be stated that the operation is also correct.

After the metropolitan test, we examined whether the comparison in another Hungarian city and with other exemplary applications could provide interesting and/ or remarkable results or not. 'MenetRendes' (http://www. kisalfoldvolan.hu/uj_menetrend/menetrendes/web.cgi ? $\mathrm{func}=$ jplan \&city=gyor\&rectransf $=1$ ) is an exemplary Hungarian route planner application in city of Györ. It contains special options, for example: age group setting, route searching depending on the travel phases (in preparation or on the way), consideration of preferences of different user groups. Consequently, the route planner applications available in this city have been examined as a next possible example area. However this area (and the other Hungarian cities as well) had to be rejected, because their route planner applications do not contain personalised setting options like in our algorithm.

\section{Conclusions}

Two contributions of the paper are:

- a method for evaluating and comparing the capabilities of existing journey planners;

- a method for rating proposed journeys that considers the personal preferences of the user.

Existing route planner applications have been examined to determine the most personalised application and to identify the exemplary settings. The developed situation analysis method is able to compare the applications and select the most personalised one.

It has been found, that the current journey planners consider hardly the personal preferences to determine the 'ideal route'.

The developed algorithm evaluates travel chains, covering walking and public transportation routes by several aspects. It takes physical properties of the routes (detailed properties of walking paths, passenger facilities and vehicles) and users' personal preferences into consideration. In the development, focus has been placed particularly on the walking phase because walking plays an important linking role in the travel chains.

Lessons learnt:

I. during comparative review of personalization settings of existing journey planners:

- route planner applications are ever changing, therefore the qualifier numbers are not permanent;

- during determination of the qualifier numbers subjectivity are to be avoided;

II. during development of the algorithm:

- realization of logical and temporal interdependences of setting options (Table 6 and 7) requires advanced programming techniques;

III. during illustration of the benefits of the algorithm:

- appropriate example area needs contain all kind of hindrances, several routes and modes;

- detailed properties of the routes are to be collected.

As a result, the route suggestions of the algorithm are much more detailed and closer to reality than the results of the existing applications. Accordingly, the route selection decisions become easier and travelling is more comfortable.

Our future research plans:

- survey the passenger demands and expectations for journey planner applications using specific AHP method;

- analyse stated and revealed personalized preferences;

- examine the time-dependent value of information on side of operators and travellers;

- modelling the network as a hypergraph (focusing on the transfer phase) in coherence with this evaluation method. 


\section{Acknowledgements}

TÁMOP-4.2.2.C-11/1/KONV-2012-0012: 'Smarter Transport' - IT for co-operative transport system - The Project is supported by the Hungarian Government and cofinanced by the European Social Fund.

\section{References}

Bekhor, S.; Cohen, Y.; Solomon, C. 2013. Evaluating long-distance travel patterns in Israel by tracking cellular phone positions, Journal of Advanced Transportation 47(4): 435-446. http://dx.doi.org/10.1002/atr.170

Cheng, Y.-H. 2011. Evaluating web site service quality in public transport: evidence from Taiwan high speed rail, Transportation Research Part C: Emerging Technologies 19(6): 957974. http://dx.doi.org/10.1016/j.trc.2011.04.003

Chorus, C. G.; Timmermans, H. J. P. 2011. Personal intelligent travel assistants, in A. De Palma, R. Lindsey, E. Quinet, R. Vickerman (Eds.). A Handbook of Transport Economics, 604-623.

Chorus, C. G.; Walker, J. L.; Ben-Akiva, M. 2013. A joint model of travel information acquisition and response to received messages, Transportation Research Part C: Emerging Technologies 26: 61-77.

http://dx.doi.org/10.1016/j.trc.2012.07.002

Csiszár, C. 2013. Model of multimodal mobility coordination and guiding system, International Journal of Engineering and Innovative Technology 3(6): 125-132.

Duleba, S.; Mishina, T.; Shimazaki, Y. 2012. A dynamic analysis on public bus transport's supply quality by using AHP, Transport 27(3): 268-275. http://dx.doi.org/10.3846/16484142.2012.719838

Dziekan, K.; Kottenhoff, K. 2007. Dynamic at-stop real-time information displays for public transport: effects on customers, Transportation Research Part A: Policy and Practice 41(6): 489-501. http://dx.doi.org/10.1016/j.tra.2006.11.006

Esztergár-Kiss, D.; Csiszár, C. 2015. Evaluation of multimodal journey planners and definition of service levels, International Journal of Intelligent Transportation Systems Research 13(3): 154-165. http://dx.doi.org/10.1007/s13177-014-0093-0

Ettema, D.; Timmermans, H. 2006. Costs of travel time uncertainty and benefits of travel time information: conceptual model and numerical examples, Transportation Research Part C: Emerging Technologies 14(5): 335-350. http://dx.doi.org/10.1016/j.trc.2006.09.001

Ganti, R. K.; Ye, F.; Lei, H. 2011. Mobile crowdsensing: current state and future challenges, IEEE Communications Magazine 49(11): 32-39. http://dx.doi.org/10.1109/MCOM.2011.6069707

Grotenhuis, J.-W.; Wiegmans, B. W.; Rietveld, P. 2007. The desired quality of integrated multimodal travel information in public transport: customer needs for time and effort savings, Transport Policy 14(1): 27-38.

http://dx.doi.org/10.1016/j.tranpol.2006.07.001

Jou, R.-C.; Lam, S.-H.; Liu, Y.-H.; Chen, K.-H. 2005. Route switching behavior on freeways with the provision of different types of real-time traffic information, Transportation Research Part A: Policy and Practice 39(5): 445-461. http://dx.doi.org/10.1016/j.tra.2005.02.004

Juhász, M.; 2013. Travel demand management - possibilities of influencing travel behaviour, Periodica Polytechnica Transportation Engineering 41(1): 45-50. http://dx.doi.org/10.3311/PPtr.7096
Kenyon, S.; Lyons, G. 2003. The value of integrated multimodal traveller information and its potential contribution to modal change, Transportation Research Part F: Traffic Psychology and Behaviour 6(1): 1-21. http://dx.doi.org/10.1016/S1369-8478(02)00035-9

Kramers, A. 2014. Designing next generation multimodal traveler information systems to support sustainabilityoriented decisions, Environmental Modelling \& Software 56: 83-93. http://dx.doi.org/10.1016/j.envsoft.2014.01.017

Leviäkangas, P. 2011. Building value in ITS services by analysing information service supply chains and value attributes, International Journal of Intelligent Transportation Systems Research 9(2): 47-54. http://dx.doi.org/10.1007/s13177-011-0029-x

Li, J.-Q.; Zhou, K.; Zhang, L.; Zhang, W.-B. 2012. A multimodal trip planning system with real-time traffic and transit information, Journal of Intelligent Transportation Systems: Technology, Planning, and Operations 16(2): 60-69. http://dx.doi.org/10.1080/15472450.2012.671708

Mandloi, D.; Thill, J.-C. 2010. Object-oriented data modeling of an indoor/outdoor urban transportation network and route planning analysis, GeoJournal Library 99: 197-220. http://dx.doi.org/10.1007/978-90-481-8572-6_11

Molin, E. J. E.; Chorus, C. G. 2004. Willingness to pay for personalized dynamic public transport information services, in TRB 83rd Annual Meeting, 11-15 January 2004, Washington, DC.

Ortúzar, J. de D.; Willumsen, L. G. 2011. Modelling Transport. 4 th edition. Wiley. $606 \mathrm{p}$.

Šimunović, L.; Bošnjak, I.; Mandžuka, S. 2009. Intelligent transport systems and pedestrian traffic, Promet Traffic\& Transportation 21(2): 141-152. http://dx.doi.org/10.7307/ptt.v21i2.220

Sivilevičius, H.; Maskeliūnaite, L. 2010. The criteria for identifying the quality of passengers' transportation by railway and their ranking using AHP method, Transport 25(4): 368-381. http://dx.doi.org/10.3846/transport.2010.46

Szabo, R.; Farkas, K.; Wiandt, B. 2013. Measurements of a real-time transit feed service architecture for mobile participatory sensing, in 2013 IFIP Wireless Days (WD), 13-15 November 2013, Valencia, Spain, 1-4. http://dx.doi.org/10.1109/WD.2013.6686542

Thill, J.-C.; Dao, T. H. D.; Zhou, Y. 2011. Traveling in the threedimensional city: applications in route planning, accessibility assessment, location analysis and beyond, Journal of Transport Geography 19(3): 405-421.

http://dx.doi.org/10.1016/j.jtrangeo.2010.11.007

Van Der Laan, J. D.; Heino, A.; De Waard, D. 1997. A simple procedure for the assessment of acceptance of advanced transport telematics, Transportation Research Part C: Emerging Technologies 5(1): 1-10. http://dx.doi.org/10.1016/S0968-090X(96)00025-3

Van Oort, N.; Van Nes, R. 2006. Service regularity analysis for urban transit network design, in 10th International Conference on Computer-Aided Scheduling of Public Transport (CASPT 2006), 21-23 June 2006, Leeds, UK, 1-26.

Watkins, K. E.; Ferris, B.; Borning, A.; Rutherford, G. S.; Layton, D. 2011. Where is my bus? Impact of mobile real-time information on the perceived and actual wait time of transit riders, Transportation Research Part A: Policy and Practice 45(8): 839-848. http://dx.doi.org/10.1016/j.tra.2011.06.010

Yuen, J. K. K.; Lee, E. W. M.; Lo, S. M.; Yuen, R. K. K. 2013. Intelligence-based route selection model of passenger flow in a transportation station, in TRB 92nd Annual Meeting Compendium of Papers, 13-17 January 2013, Washington, DC, 1-20. 